\title{
The double immunostaining of CDI33 and Ki-67 favours a significant co-localization pattern in fibroblastic subtype of meningiomas
}

\section{Podwóine znakowanie immunologiczne CD133 i Ki-67 wskazuje na ich istotnq wspótlokalizacię w podtypie włóknistym oponiaków}

\author{
Baki S. Albayrak', Ozgur Ismailoglu', Gamze Tanriover², Eralp N. Cetinalp³ ${ }^{3}$ Necdet Demir ${ }^{2}$ \\ 'Department of Neurosurgery, Suleyman Demirel University Medical Faculty Hospital, Isparta, Turkey \\ 2Department of Histology and Embryology, Akdeniz University Medical Faculty Hospital, Antalya, Turkey \\ ${ }^{3}$ Department of Neurosurgery, Etlik Training and Teaching Hospital, Ankara, Turkey
}

Neurologia i Neurochirurgia Polska 2011; 45, 5: 467-473

\begin{abstract}
Background and purpose: A unique molecular and/or cellular marker for meningiomas, the most common intracranial tumours, has not been identified yet.

Material and methods: We investigated the co-localization fraction of CD133/Ki-67 in meningioma tissue array slide composed of 80 meningioma tissue samples of various histological variants. CD133 - a cell membrane stem cell marker - was previously proved to be associated with the initiation and progression of intracerebral gliomas and medulloblastomas.

Results: Immunohistochemical co-localization of CD133/ $\mathrm{Ki}-67$ was significantly higher in fibroblastic variant than in meningothelial and transitional subtypes. However, since there were only 3 atypical and 1 malignant meningioma spots in the tumour tissue array slide, it is difficult to draw a firm conclusion regarding the actual co-localization percentage and persistence of CD133/Ki-67 in atypical and malignant meningiomas.

Conclusions: Far higher co-staining percentage of CD133/ $\mathrm{Ki}-67$ in fibroblastic meningioma samples compared to meningothelial subtype, a histological meningioma variant, architectonically resembling the non-neoplastic meningeal cells, gave us the impression that CD133 may play a role in the formation and progression of fibroblastic meningioma variants.
\end{abstract}

\section{Streszczenie}

Wstęp i cel pracy: Nie określono dotąd unikalnego znacznika molekularnego lub komórkowego dla oponiaków, najczęstszych guzów wewnątrzczaszkowych. Wcześniej wykazano, że CD133 - znacznik błony komórkowej komórek macierzystych - jest związany z zapoczątkowaniem, a także wzrostem wewnątrzczaszkowych glejaków i rdzeniaków płodowych. Materiał i metody: Zbadano odsetek współlokalizacji CD133/Ki-67 w zestawach macierzy tkankowych oponiaków, złożonych z próbek 80 rozmaitych odmian histologicznych oponiaków.

Wyniki: Immunohistochemiczna współlokalizacja CD133 i Ki-67 była stwierdzana istotnie częściej w podtypie włóknistym oponiaka niż w podtypach meningotelialnym lub przejściowym. Ze względu na małą liczbę preparatów oponiaków atypowych (3) oraz złośliwych (1) w badanej macierzy tkankowej trudno wyciągnać jednoznaczne wnioski dotyczące rzeczywistego odsetka współlokalizacji i utrzymywania się CD133/Ki-67 w oponiakach atypowych i złośliwych.

Wnioski: Znacząco większy odsetek wspólnie występującej reaktywności CD133/Ki-67 w preparatach oponiaka włóknistego w porównaniu z podtypem meningotelialnym, którego architektonika przypomina nienowotworowe komórki opon,

Correspondence address: Assoc. Prof. Baki S. Albayrak, MD, Department of Neurosurgery, Suleyman Demirel University, Medical School Hospital, 32260, Cunur district, Isparta, Turkey, phone 0532 3089772, fax 02462112450 , e-mail: serdarbaki@gmail.com

Received: 2.10.2010; accepted: 22.03.2011 
The persistency and the validity of this finding need to be verified by further histopathological and molecular research in order to clarify the possible role of CD133 in meningiogenesis.

Key words: meningioma, fibroblastic, CD133, Ki-67, tissue array, co-localization.

\section{Introduction}

Meningiomas, the most common intracranial tumours, constitute almost one-third of all brain tumours. They are thought to be of neuroectodermal origin based on the striking ultrastructural and histological resemblance to arachnoid cells [1-3]. Meningiomas were defined well cytogenetically but they are poorly understood molecularly. Thus, histopathological grading of meningiomas does not necessarily predict its clinical course, particularly in atypical meningiomas [4]. Additionally, recent findings in molecular genetics provide strong evidence that meningiogenesis is a dynamic process with tumour suppressor $N F-2$ gene deletion on chromosome 22 and several other genetic aberrations including the deletion of the INK4a-ARF locus [5]. In this regard, cellular origin of meningiomas with a unique molecular marker still needs to be clarified.

For this purpose, in a meningioma tissue array consisting of 80 meningiomas of various histopathological subsets, we investigated the co-localization pattern of CD133, a cell-surface antigen - a proposed molecular signature for meningioma cells with Ki-67 nuclear antigen which is expressed in dividing cells in all phases of the cell cycle except $\mathrm{G}_{0}$. Even though the exact biological function of CD133, a cell-surface antigen, is not known, it is a marker for stem and progenitor cells. CD133 was also widely expressed in cancers, including some leukaemias and brain tumours, mostly in gliomas and medulloblastomas. According to our hypothesis, meningioma cells with Ki-67 expression may have the potential to be the pluripotent meningioma initiating cells since $\mathrm{Ki}-67$ antigen is mostly expressed in dividing cells and CD133, a cell-surface antigen, was proposed as a molecular marker for these candidate meningioma-initiating cells. Thus, for the first time in the literature, coexpression fraction and consistency of CD133 and $\mathrm{Ki}-67$ in various meningioma subtypes were investigated immunohistochemically in our study. sprawia wrażenie, że CD133 może odgrywać rolę w powstawaniu i rozwoju oponiaków włóknistych. Trafność tego spostrzeżenia wymaga weryfikacji w dalszych badaniach histopatologicznych i molekularnych w celu wyjaśnienia możliwej roli CD133 w powstawaniu oponiaków.

Słowa kluczowe: oponiak, włóknisty, CD133, Ki-67, macierz tkankowa, współlokalizacja.

\section{Material and methods}

The efficacy of the below-explained double immunostaining procedure was confirmed in several human meningioma paraffin slides (WHO grade I meningioma) with a negative control prior to proceeding to the immunostaining of the meningioma tissue array slide (Fig. 1).

For CD133 immunohistochemistry, paraffin slide consisting of 80 meningioma tissue samples (meningioma of central nerve tissue array \# MG801, US Biomax, Inc., 1100, TaftSt. Rockville, MD 20850, USA) was deparaffinized and blocked for endogenous peroxidase activity with methanol containing $3 \% \mathrm{H}_{2} \mathrm{O}_{2}$ for $15 \mathrm{~min}$ and for nonspecific binding with universal blocking reagent (BioGenex, San Ramon, CA, USA) for $7 \mathrm{~min}$ at room temperature. Anti-mouse CD133 (Cat \# 14-1331-80, eBioscience, Inc, San Diego, CA, USA) diluted in dilution buffer $(1 / 100)$ was applied for 1 hour at room temperature in a humidified chamber. After several washes in PBS, the section was incubated with biotinylated goat anti-mouse IgG secondary antibody (1/400 dilution, Vector Lab., Burlingame, CA, USA) for 45 min followed by LSAB streptavidin-peroxidase complex (Dako, Carpinteria, CA, USA) incubation for $30 \mathrm{~min}$ and was rinsed with PBS. Antibody complex was visualized by incubation with diaminobenzidine (DAB) chromogen (BioGenex). After several washes in PBS, the section was incubated with a Ki-67 (Cat \# RM-9106-S0; ThermoScientific, Fremont, CA, USA) rabbit monoclonal antibody ( $1 / 100$ dilution) overnight at $4^{\circ} \mathrm{C}$. Following the washing steps in PBS, the section was incubated with anti-rabbit biotinylated goat anti-mouse $\operatorname{IgG}$ secondary antibody (1/400 dilution, Vector Lab. Burlingame, CA, USA) for $45 \mathrm{~min}$ followed by LSAB streptavidin-peroxidase complex (Dako, Carpinteria, CA, USA) incubation for 30 min and rinsed with PBS. Antibody complex was visualized by incubation with 3-amino-9-ethylcarbazole (AEC) chromogen (Thermoscientific). The section was counterstained with Mayer's haematoxylin (Dako), dehydrated, mounted and examined by a Zeiss-Axioplan 

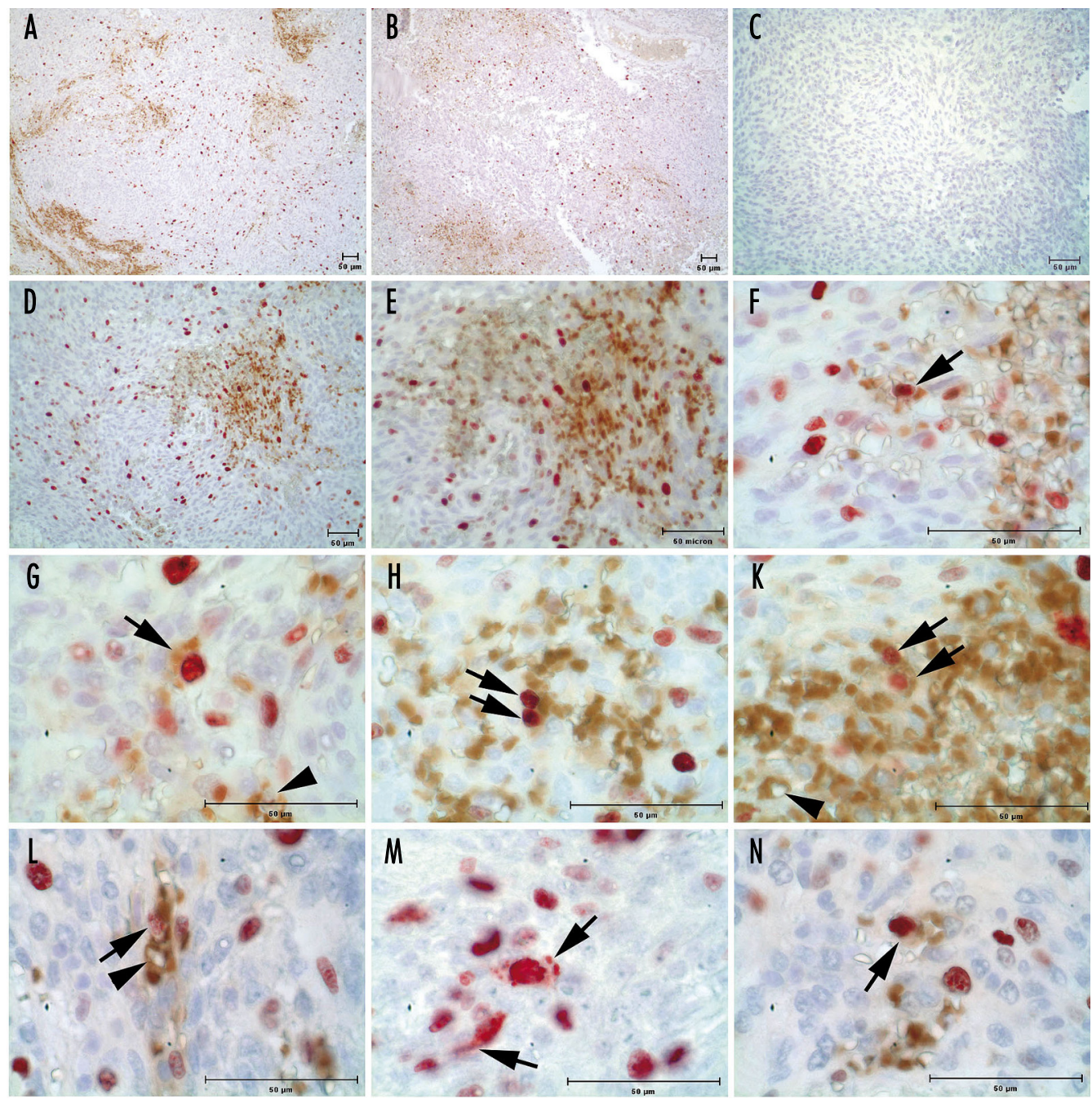

Fig. 1. Human meningioma paraffin trial slide double stained with (D133 and Ki-67. A, B) Total area 10×, C) negative control 20×, D) 20×, E) 40×, F-N) $100 \times$ cell staining, arrows: double staining (CD133/Ki-67), arrowheads: CD133 staining, CD133 cytoplasmic staining with DAB (brown), Ki-67 nuclear staining with AEC (red)

(Oberkochen, Germany) microscope and the co-localization ratio of $\mathrm{CD} 133$ and $\mathrm{Ki}-67$ staining was calculated using a $40 \times$ magnification high-power field for each meningioma tissue sample.

Mean fraction of co-localization in various meningioma subtypes was analysed applying a non-parametric Kruskal-Wallis test with a significance level of 0.05 (SPSS 15.0 software).

\section{Results}

Immunostaining of CD133 and Ki-67 was satisfactorily positive in 76 of 80 (95\%) meningioma tissues samples in the tumour tissue array slide. Number of tumour subtypes and the mean percent of co-localization are de-
Table 1. Number of specific meningioma subtypes and the mean percentage of CDI33 and Ki-67 expression for each meningioma group

\begin{tabular}{|lcc|}
\hline $\begin{array}{l}\text { Meningioma } \\
\text { subtype }\end{array}$ & $\begin{array}{c}\text { Number and } \\
\text { percentage of each } \\
\text { meningioma } \\
\text { subtype }\end{array}$ & $\begin{array}{c}\text { Mean \% of } \\
\text { co-localization } \\
\text { (magnification } \times \mathbf{4 0} \text { ) }\end{array}$ \\
\hline Meningothelial & $17(22 \%)$ & $1.50 \%$ \\
\hline Fibroblastic & $37(49 \%)$ & $3.67 \%$ * \\
\hline Transitional & $14(18.5 \%)$ & $1.60 \%$ \\
\hline Psammomatous & $2(2.6 \%)$ & $0.25 \%$ \\
\hline Microcystic & $2(2.6 \%)$ & $0.0 \%$ \\
\hline Atypical & $3(4 \%)$ & $1.30 \%$ \\
\hline $\begin{array}{l}\text { Malignant } \\
\text { (papillary type) }\end{array}$ & $1(1.3 \%)$ & $1.50 \%$ \\
\hline
\end{tabular}

${ }^{*}$ Mean percentage of co-localization is significantly higher in fibroblastic meningioma subtype than the other subtypes 


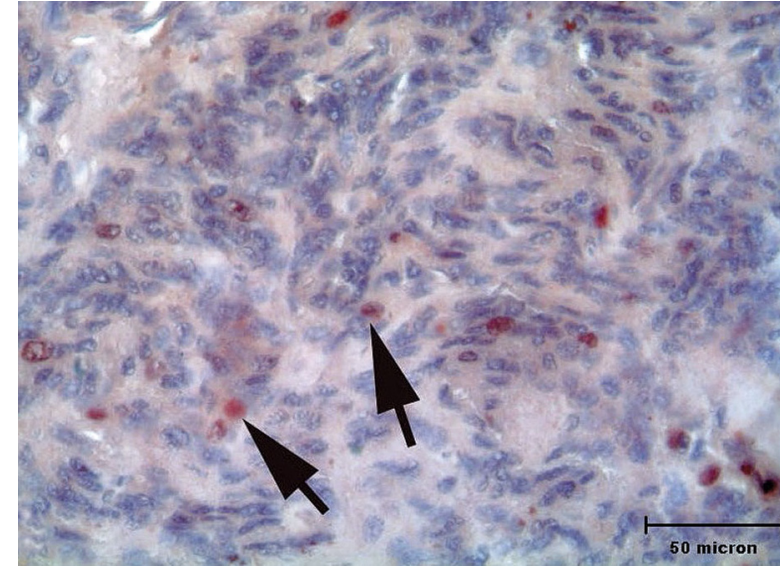

Fig. 2. Fibroblastic meningioma spots in tissue micro-array slide double stained with CD133 and Ki-67

picted in Table 1. Co-localization fraction was significantly higher in fibroblastic meningioma subtypes than those of other histological variants including meningothelial, transitional, psammomatous, microcytic, atypical, and malignant (papillary) types (Figs. 2-4) ( $p<0.0001)$.

\section{Discussion}

Although all meningioma subsets are thought to be derived from meningothelial cells, they display a wide spectrum of histological variants. The WHO classification in 2007 reported that meningothelial, fibrous and transitional (combination of meningothelial and fibroblastic appearance) subtypes are the most frequent subtypes. While grade I meningiomas (meningothelial, fibroblastic, transitional, psammomatous, angiomatous, microcystic, secretory, lymphoplasmacyte-rich, metaplastic) are generally treated satisfactorily, grade II (atypical, chordoid and clear cell tumours) and grade III (anaplastic, papillary, and rhabdoid tumours) subtypes tend to behave more aggressively with higher recurrence rates $[4,6]$. Meningothelial (also known as syncytial meningioma) is the most common variant and is composed of cells with aberrant borders. Fibrous tissue is characteristically absent and whorls and psammoma bodies are less frequently encountered in meningothelial tumours. The meningioma cells exhibit round to oval nuclei and variable numbers of nuclear-cytoplasmic inclusions surrounded by marginated chromatin. Glycogen containing inclusions can also be observed in this variant, giving the classical ground-glass appearance. Fibrous meningiomas are less common than the meningothelial variant and consist of elongated spindle cells with a variable degree of col- lagen. Nuclei are often hyperchromatic and more elongated than those of the meningothelial and transitional variants. Transitional meningiomas are the intermediate subtype between meningothelial and fibrous patterns. Generally, lobules appear syncytial with the elongated fibrous cells located in the periphery. Overall, the most reliable diagnostic marker for meningioma is cell-surface immunoreactivity for epithelial membrane antigen (EMA) with more marked staining in meningothelial and transitional lesions than in fibrous tumours. Diffuse immunoreactivity for vimentin is also seen in all variants of meningioma. Cytokeratin reactivity is typically observed in secretory meningiomas. However, regarding the cellsurface markers, only CD44 expression in meningioma cells was extensively investigated and it was agreed that the over-expression of CD44 was associated with increased migration ability and anaplasia in meningioma cells [7,8]. Sainio et al. [9] demonstrated the co-localization of the NF2 gene product merlin protein with CD44 and the interaction of CD44 with cytoskeleton via ezrin, radixin, and moesin proteins - structural relatives of merlin protein. Even though the data on CD44 function in meningioma cells support the idea that CD44 contributes to the invasiveness and anaplasia of meningiomas, some authors have claimed that CD44 may have a biphasic effect on meningioma cells - that is, CD44 promotes migration of meningiomas cells in low concentrations, whereas it causes inhibition in higher concentrations [8]. Notably, it is evident that CD44, as a cell surface marker, has interactions with small cellular membrane proteins such as ezrin, moesin, and merlin, which is encoded by the NF2 gene, a tumour suppressor gene, and its biallelic inactivation was detected in more than half of meningiomas $[9,10]$.

To our knowledge, there is no single report regarding the expression pattern of CD133 in meningioma cells. However, numerous studies have demonstrated that only CD133-positive glioblastoma multiforme (GBM) cells have tumour-initiating potential. Cancer stem cells in gliomas were first proposed by Singh et al. [11] and the authors proved that only CD133-positive glioma cells have the self-renewal and self-propagating capacity. Additionally, cancer stem cells derived from GBM are capable of recapitulating original tumours when transplanted into nude mice. Taken together, CD133 plays a crucial role in GBM initiation and progression. In our study, the CD133/Ki-67 co-expression fraction was significantly higher in fibroblastic meningiomas than in other meningioma variants. However, since there were only 3 atypical and 1 malignant meningioma spots in the 

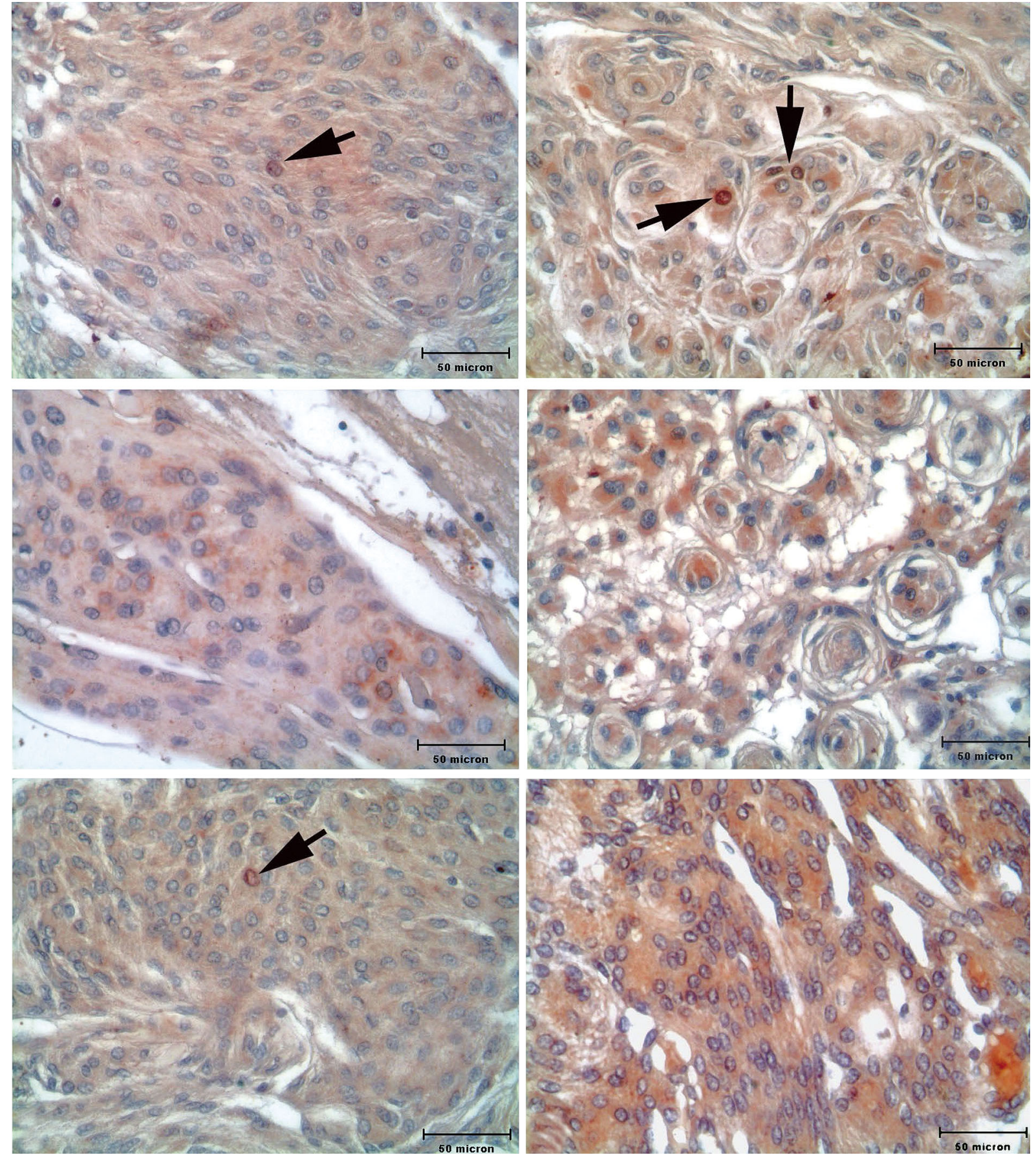

Fig. 3. Meningothelial meningioma spots in tissue micro-array slide double stained with CDI33 and Ki-67

tumour tissue array slide, it is difficult to draw a conclusion regarding the actual co-localization percentage and persistence of CD133/Ki-67 in atypical and malignant meningiomas. Nevertheless, the far higher co-staining percentage of CD133/Ki-67 in fibroblastic meningioma samples compared to meningothelial subtype, a histological meningioma variant, architecturally resembling the non-neoplastic meningeal cells, gave us the impression that CD133 may play a role in the formation and progression of fibroblastic meningioma variants. 

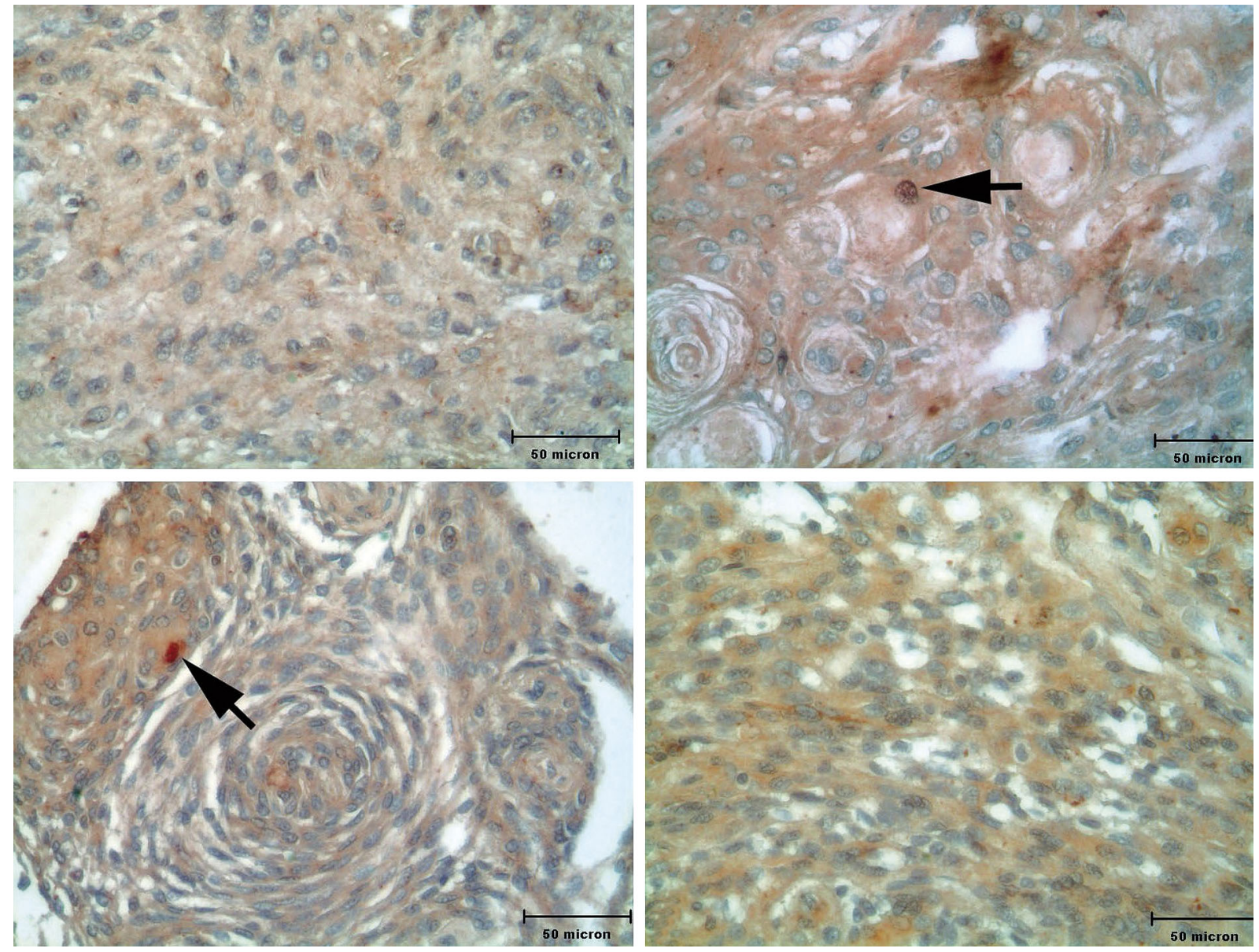

Fig. 4. Transitional (mixed) meningioma spots in tissue micro-array slide double stained with CD133 and Ki-67. CD133 cytoplasmic staining with DAB (brown in colour) and Ki-67 nuclear staining with AEC (red in colour)

\section{Conclusions}

1. The immunohistopathologically demonstrated persistent and significant co-staining pattern of CD133/ Ki-67 in fibroblastic meningioma cells still needs to be verified in various tumour samples obtained from patients with meningiomas.

2. The further investigation of the possible role of CD133 in meningiogenesis may contribute to the understanding of the diversity of meningiomas at the cellular and molecular level.

\section{Disclosure}

The authors report no conflict of interest.

\section{References}

1. Albayrak B.S., Black P.M. The origin of meningiomas. In: Pamir M.N., Black P.M., Fahlbusch R. (eds.). Meningio- mas: A Comprehensive Text. $1^{\text {st }}$ ed. Saunders, Philadelphia 2010 , p. 53.

2. Black P.M. Meningiomas. Neurosurgery 1993; 32: 643-657.

3. Yamashima T. On arachnoid villi and meningiomas: functional implication of ultrastructure, cell adhesion mechanisms, and extracellular matrix composition. Pathol Oncol Res 1996; 2: 144-149.

4. Kleihues P., Louis D.N., Scheithauer B.W., et al. The WHO classification of tumors of the nervous system.J Neuropathol Exp Neurol 2002; 61: 215-225 [discussion: 226-229].

5. Kalamarides M., Stemmer-Rachamimov A.O., Takahashi M., et al. Natural history of meningioma development in mice reveals a synergy of $\mathrm{Nf2}$ and p16(Ink4a) mutations. Brain Pathol 2008; 18: 62-70.

6. Riemenschneider M.J., Perry A., Reifenberger G. Histological classification and molecular genetics of meningiomas. Lancet Neurol 2006; 5: 1045-1054.

7. Suzuki S.O., Iwaki T., Kitamoto T., et al. Differential expression of CD44 variants among meningioma subtypes. Clin Mol Pathol 1996; 49: 140-146.

8. Rooprai H.K., Liyanage K., King A., et al. CD44 expression in human meningiomas: an immunocytochemical, immunohistochemical and flow cytometric analysis. Int J Oncol 1999; 14: 855-860. 
9. Sainio M., Zhao F., Heiska L., et al. Neurofibromatosis 2 tumor suppressor protein colocalizes with ezrin and CD44 and associates with actin-containing cytoskeleton. J Cell Sci 1997; 110: 2249-2260.

10. Kalamarides M., Niwa-Kawakita M., Leblois H., et al. Nf2 gene inactivation in arachnoidal cells is rate-limiting for meningioma development in the mouse. Gene Dev 2002; 16: 1060-1065.

11. Singh S.K., Clarke I.D., Terasaki M., et al. Identification of a cancer stem cell in human brain tumors. Cancer Res 2003; 63: 5821-5828. 